\title{
PEMBELAJARAN BERBASIS LINGKUNGAN (Realisasi Ekotologi Intergralistik di Perguruan Tinggi)
}

\author{
Oleh: Ali Halidin
}

\section{Sekolah Tinggi Agama Islam Negeri (STAIN) Parepare Email: alihalidin766@gmail.com}

\begin{abstract}
Duality is one reality (God One), in this universe consisting of only two common types, God and not God; The Creator and the Creature. The first type has only one member namely Allah SWT. He alone is the eternal God, the transcendent Creator. There is nothing similar to Him, while the second is the composition of God's created being made up of nature and all its contents, the first impossible, but the second extinction, the extinction of nature and of life.

Ideality is a natural power that synergizes with the power of human understanding and belief. Understanding is used to understand the will of God through observation and on the basis of creation, the will of the ruler who must be actualized in space and time, participate in world activities and create desired change. Understanding the application of recognition of knowledge of truth as a principle of knowledge. Tawheed is the recognition that God is, is and is One. The recognition that the truth can be known and man is able to achieve it, through the process of learning (understanding).

This study focuses on natural studies and conceptions in interpreting Islamic ecology among students and students in Indonesia, and emphasizes the need to be serious. The concept of Islamic ecology is an insistence on science, to be preserved and developed. Practically its presence along with Islamic doctrine brought by Muhammad Saw. Slowly but surely, all aspects of human life, can not be separated from the process of improvement and refinement. Both with regard to simple things such as the purification of self from impurities (unclean), to matters concerning environmental sanctification, even corpses (dead).

This paper describes, there is no problem that is beneficial to human beings, unless all the problems are related even in accordance with the teachings of Islam, but sometimes this issue is not a concern by all mankind, even consider
\end{abstract}


it trivial. Considering Islam only regulates ubudiyah problems ranging from praying, fasting zakat, alms and pilgrimage. This can be seen from the lack of awareness in disposing of waste in its place. Or the lack of awareness of hygiene and consistent in maintaining the environment.

The effort of learning by prioritizing the values of environmental virtue is very necessary to be done early, start learning at Kindergarten level, up to college. This form of business is not only limited to habituation, but more than that, in the form of awareness and love that is formed in the minds of every Muslim, because the love of nature, is a form of love to Allah SWT.

\section{Keywords: Islamic Ecology, Young Generation, Nature Preservation}

\section{Pendahuluan}

Meningkatnya bencana alam dalam kurun lima tahun terakhir ini, sepatutnya menjadi pelajaran bagi manusia. Kerusakan alam yang terjadi diberbagai belahan dunia secara beriringan seakan tidak akan kunjung reda. Sejak terjadi revolusi industri sekitar 2 abad lalu, manusia memproduksi aneka macam kebutuhan hidupnya. Industrialisasi banyak mengorbankan lingkungan alam sekitar untuk dijadikan bahan "pemuas nafsu" pemenuhan segala kepentingannya tanpa mempertimbangkan dampak-dampak negatif yang ditimbulkannya. ${ }^{1}$

Ilmu ekologi hadir sebagai upaya untuk mempelajari hubungan timbal balik antara makhluk hidup dan lingkungan. Secara etimologis, kata ekologi (ecology) berasal dari bahasa Yunani, yakni gabungan dua kata oikos yang berarti rumahtangga dan kata logos yang berarti ilmu. Sedangkan Menurut al-Faruqi

\footnotetext{
${ }^{1}$ Ekologi dipahami sebagai ilmu yang mengkaji tentang proses interrelasi dan interdepensi antar organisme dalam satu wadah lingkungan tertentu secara keseluruhan.4 Pertama kali diperkenalkan oleh ahli Biologi Jerman bernama Ernest Haeckel (1834-1919) dalam kerangka disiplin ilmu biologi.5 Jadi, ilmu ini mempelajari tentang lingkungan, baik yang hidup maupun tidak hidup. Selanjutnya, makhluk hidup dipelajari dalam enam kelompok yang berbeda yaitu" individu, populasi, komunitas, ekosistem, bioma, dan biofer. Jadi ekologi mempelajari semua hal berkaitan dengan tumbuhan hewan, dan manusia. Dalam pengertian lain, ekologi merupakan sebuah ekosistem (kesatuan sistem) alam dan manusia.6 Dalam Islam eksistensi manusia dan alam sebagai sesama makhluk ciptaaan Tuhan, harus menunjukkan saling ketergantungannya. Manusialah yang harus menjaga dan melestarikan alam.7 Karenanya, penjagaan dan pemeliharaan harus dilakukan oleh manusia, sebagai penghuni yang ,paling berkuasa ${ }^{\text {ee }}$ dibandingkan makhluk hidup lainnya terhadap pengelolaan alam lingkungan.
} 
(1921-1986) ${ }^{2}$ yang dikutip al-Dasuqy, hubungan Tuhan, Manusia, dan alam sebagai sebuah kesatuan yang dipahaminya dengan konsep tauhid. Pandangan tauhid memiliki tiga prinsip realitas, yaitu; 1) Dualitas; setiap realitas selalu terdiri dari pasangan dan keduanya saling membutuhkan. Semisal, langit dan bumi, siang dan malam, adanya manusia dan alam, dan seterusnya. 2) ideasionalitas; segala ketentuan Allah yang aksiomatik berupa hukum alam (sunnatullah). Misal semua planet berdear pada porosnya yang merupakan eksistensi keberadaan planet-planet tersebut. 3) Teologi; memandang segala sesuatu sebagai bagian dari wujud Tuhan, dalam arti, segala makhluk tercipta dengan tujuan dan kemanfaatan. ${ }^{3}$

Bencana alam biasanya dipahami sebagai bencana besar yang melanda. Seperti; gunung meletus, gempa bumi, banjir bandang, tsunami, tanah longsor, kebakaran hutan yang disebabkan pemanasan. Di Indonesia beberapa peristiwa yang banyak menelan korban akibat bencana alam, salah satunya terjadinya gempa tsunami di Aceh 2004 silam, Meletusnya gunung Merapi di Jawa Tengah terjadi dalam beberapa kali antara lain tahun 2006, 2010. Diluar negeri, Gempa di Nepal yang terjadi pada 25 April 2015 berkekuatan 7,9 R menewaskan sedikitnya 1.900 orang, serta sedikitnya 4.000 korban luka. Gempa merusakkan bangunan rumah dan tempat ibadah dan lainnya. Bahkan terjadi gempa susulan pada hari berikutnya Badan Survei Geologi Amerika Serikat mencatat gempa susulan itu berkekuatan 6,7

Selain gempa yang terjadi di sebagian wilayah Indonesia, kasus pencemaran lingkungan akibat dibangunya beberapa industri-industri raksasa, turut andil dalam pencemaran dan kerusakan ekosistim lingkungan hidup. Didirikannya pabrik-pabrik telah mencemari aliran sungai-sungai dari hulu ke hilir sampai kelautan samudara dengan limbah-limbh pabrik yang membahayakan. Contoh, di Bekasi, Badan Pengelola Lingkungan Hidup (BPLH) Kota Bekasi

\footnotetext{
${ }^{2}$ Ismail Raji al-Faruqi lahir di Jaffa, Palestina 1 Januari 1921 (Abdul Sani, 1998 : 262) Ayah al-Faruqi bernama Abdul Huda al-Faruqi, sosok laki-laki yang religius dan qodi terpandang di Palestina. Pendidikan agama yang didapatkan al-Faruqi langsung dari ayahnya di rumah dan di masjid sekitar rumahnya. Awal perjalanan intelektual dimulai dengan belajar di College Des Freses (St.Yoseph) tahun 1936.

${ }^{3}$ Barat, Amerika Utara, Jepang dan berlanjut kenegara lainnya. Lihat Harun Hadiwojono, sari sejarah filsafat barat 2 9Yogyakarta: Kanisius, 1992) 13-14.
} 
memastikan air baku Kali Bekasi masih dapat diolah untuk dikonsumsi. Meskipun saat ini kondisi Kali Bekasi dalam kondisi tercemar akibat limbah industri. ${ }^{4}$

Fajar el-Dusuqy menyebut korelasi antara manusia dan alam sebagai ekoteologi integralistik. Bahwa dimasa sekarang dan kedepan manusia dituntut untuk mengembangkan IPTEK, namun di sisi lain juga dituntut untuk menjaga kelestarian lingkungan. ${ }^{5}$ Aneka macam produk manusia dalam berbagai aspeknya telah menunjukkan korelasi yang integral. Teknologi informasi dan komunikasi, dan transportasi yang semakin efektif dan efisien dan memudahkan kehidupan manusia menjadi bukti adanya jalinan integratif tersebut. Kendatipun tidak hanya sisi positif yang didapatkan manusia dalam memanfaatkan alam sekitar, namun sisi negatif pun mengirinya. Sebagai contoh adanya ekspoitasi hutan secara ilegal, berakibat adanya dampak banjir. ${ }^{6}$

Berkaitan dengan masa depan lingkungan global, masyarakat dunia, mengadakan Konferensi Tingkat Tinggi (KTT) tentang pemeliharaan lingkungan Bumi (Earth Summit) yang diikuti beberapa negara. Salah satunya yang pernah diadakan di Rio de Jeneiro pada 3-14 Juni 1992. Sebagai tindak lanjut dari kepedulian terhadap masalah ekologi, juga telah diadakan konferensi perubahan iklim Perserikatan Bangsa-Bangsa bahas tentang pemanasan global (Global Warming) yang diadakan di Nusa Dua Bali, Indonesia pada 3-14 Desember 2007. Konferensi yang diadakan oleh Badan PBB berupa United Nations Framework Convention on Climate Change (UNFCC) ini merupakan pertemuan ke-13 yang diikuti sekitar sembilan ribu peserta perwakilan dari 186 Negara dan sekitar tiga ratus LSM internasional. ${ }^{7}$

Secara historis, perhatian lingkungan hidup telah muncul di media massa sejak tahun 1960-an. di Indonesia diselenggarakannya Seminar Pengelolaan

\footnotetext{
${ }^{4}$ Abdullah M. Surjaya “Tercemar Limbah. Air Kali Bekasi Masih Layak Konsumsi”, diposting senin, 9 Februari 2015. source:http://metro.sindonews.com/read/961753/31/tercemar-limbah-air-kali-bekasi-masihlayak-konsumsi-1423397037. Diakses pada 26 Mei 2

${ }^{5}$ Fajar el-Dusuqy, Ekologi al-Qur"an; Menggagas Ekoteologi-Integralistik, e-Jurnal Kaunia, Vol. IV, No. 2, Oktober 2008, 173-189. Dalam www.digilib.uin-suka.ac.id

${ }^{6}$ Fajar el-Dusuqy, Ekologi al-Qur'"an; Menggagas Ekoteologi-Integralistik, e-Jurnal Kaunia, Vol. IV, No. 2, Oktober 2008, 173-189, http://digilib.uin-suka.ac.id/id/eprint/710 . lihat juga Ismail Raji al- Faruqi, Tawhid: Its Implication for Thought and Life (New York: Machmillan Publishing, 1982), 56.

${ }^{7}$ Kyoto Protocol. "United Nations framework convention on climate change." Kyoto Protocol, Kyoto 19 (1997), h. 12
} 
Lingkungan Hidup dan Pembangunan Nasional oleh Universitas Padjajaran di Bandung pada tanggal 15-18 Mei 1972. Seminar itu merupakan seminar pertama tentang lingkungan hidup yang diadakan di Indonesia. Karena itu, butuh kesinambungan dari berbagai pihak terutama stakeholder dalam bidang keagamaan (Islam) dalam menanamkan pentingnya menjaga kelestarian alam sekitar dalam semua aspeknya. Khususnya generasi muda yang akan menjadi tolok ukur dari sebuah kebijakan yang ambigu.

\section{Pembahasan}

\section{Pemerintah dalam Pelestarian lingkungan}

Pembahasan ekologi secara universal mencakup segala aspek kehidupan manusia, meliputi tanah, udara dan air. Segala fasilitas di bumi tersebut merupakan pekerjaan rumah bagi manusia agar melestarikannya bukan untuk membuat kerusakan. Perusakan terhadap lingkungan sekitar adalah sebuah pantangan yang perlu diberikan penyadaran kepada setiap individu. Pencemaran terhadap lingkungan meliputi beberapa hal, yaitu: ${ }^{8}$

Pertama; Pencemaran lingkungan yang berkaitan dengan air sebagai bagian dari kebutuhan sehari-hari manusia. Sebagai contoh, pencemaran perairan sungai, terutama di daerah perkotaan, dengan berdirinya pabrik yang membuang limbah di aliran sungai menjadikan sungai akan semakin dangkal dan mengakibatkan banjir.

Kedua; Pencemaran lingkungan yang berkaitan dengan udara. Bagian yang teramat penting ini juga menjadi problematika sendiri dikalangan perkotaan. Peningkatan volume kendaraan dan atau transportasi udara dengan bahan bakarnya telah menjadikan udara diperkotaan tercemari (polusi udara). Termasuk berdirinya pabrik yang semakin banyak didaerah-daerah.

Ketiga; Pencemaran lingkungan yang berkaitan dengan tanah. Penyebaran tanah perkotaan semakin padat dengan bangunan-bangunan rumah, perkantoran dan gedung-gedung pabrik yang semakin menjadikan sempit lahan dan tanah perkotaan. Sehingga sering terjadi kebakaran akibat dari konsleting listrik.

${ }^{8}$ Siahaan, Nommy Horas Thombang. Hukum Lingkungan dan Ekologi Pembangunan. Erlangga, 2004. 
Kebakaran itu menyebabkan bertambah parahnya pencemaran lingkungan berupa polusi udara dan lain sebagainya.

Pencemaran dalam berbagai aspek itu, sejatinya tujuan awalnya merupakan sebuah efisiensi dari semua kebutuhan manusia itu sendiri. Hanya saja, berbagai dampak yang ditimbulkannya pun mengalami peningkatan diluar prediksi ilmu pengetahuan. Disinilah, tugas utama dari ilmu pengetahuan sekaligus menciptakan kesejahteraan manusia dengan mengantisipasi segala kemungkinan terjelek dari terancamnya kehidupan manusia, oleh karena ketidak seimbangan alam ataupun gangguan alam, yang mengakibatkan bencana alam, yang akan menyebabkan kehidupan manusia menjadi punah.

Global Warming, merupakan salah satu dampak ketidak seimbangan pola hidup manusia dengan alam, kasus ini menjadi masalah yang krusial terkait pelestarian lingkungan, Beberapa gejala yang dapat dijadikan sebagai indikator adanya krisis ekologi ini, yang terpenting adalah semakin panasnya suhu bumi. Pemanasan global diperkirakan telah menyebabkan perubahan-perubahan sistem terhadap ekosistem di bumi, antara lain; perubahan iklim yang ekstrim, mencairnya es sehingga permukaan air laut naik, serta perubahan jumlah dan pola presipitasi. Adanya perubahan sistem dalam ekosistem ini telah memberi dampak pada kehidupan di bumi seperti terpengaruhnya hasil pertanian, hilangnya gletser dan punahnya berbagai jenis hewan. ${ }^{9}$

Pemanasan global ini, disebabkan karena beberapa hal, yaitu: 1) Efek Rumah Kaca, 2) efek umpan Balik, 3) variasi matahari, 4) kurangnya rekayasa air embun, kolam damai, 5) hutan digunduli (pembalakan), kesemuanya berdampak kepada cuaca, tinggi permukaan air laut, pantai, pertanian, kehidupan hewan liar dan juga kesehatan manusia. Khusus berkaitan dengan bertambahnya gas rumah kaca untuk memperlambatnya ada dua cara; pertama; mencegah karbon dioksida dilepas ke atmosfer dengan menyimpan gas tersebut atau komponen karbon-nya

${ }^{9}$ Root, Terry L., et al. "Fingerprints of global warming on wild animals and plants." Nature 421.6918 (2003): 57-60. 
ditempat lain yang disebut dengan cara sequestration (menghilangkan karbon). Kedua; mengurangi produksi gas rumah kaca. ${ }^{10}$

Pemerintah Indonesia telah menjelaskan dalam undang-undang mengenai lingkungan hidup yang berbunyi, "pemerintah berkewajiban menumbuhkan dan mengembangkan kesadaran akan tanggungjawabnya dalam pengelolaan lingkungan hidup melalui penyuluhan, bimbingan, pendidikan dan penelitian tentang lingkungan hidup. Undang-undang tersebut tahun 1997 kemudian dirubah dengan redaksi "dimana setiap orang atau anggota masyarakat berkewajiban memelihara fungsi lingkungan hidup serta mencegah dan menanggulangi pencemaran dan perusakan lingkungan hidup. ${ }^{11}$

Sebagaimana dikutip oleh Ghazali menyebutkan wujud dari undangundang itu antara lain melibatkan kelompok-kelompok masyarakat yang terdiri dari pemimpin agama, wanita, pemuda, wartawan dan organisasi masyarakat lainnya yang bergerak di bidang lingkungan. Sebagaimana dikuatkan oleh Qodri Azizy bahwa etika lingkungan dalam segala aspeknya hendaknya dimasyarakatkan dalam rangka menjaga kelangsungan hidup umat manusia yang menjunjung tinggi nilai-nilai etika demi kesejahteraan bersama, ditambahkan olehnya bahwa etika lingkungan ini cara pengajarannya dengan praktek, bukan hanya sekedar teoritis. Karena itu, perhatian terhadap pelestarian lingkungan harus ditanamkan sejak dini kepada generasi muda, baik dilembaga formal maupun informal secara intensif dan berkesinambungan. ${ }^{12}$

Dengan demikian, betapapun banyak dan kuat sebuah peraturan yang diundang-undangkan bila tidak disertai dengan wujud konkrit dalam kehidupan sehari-hari oleh semua pihak baik pemerintah maupun masyarakat, maka harapan terhadap situasi dan kondisi lingkungan yang nyaman, sehat, dan lestari akan mustahil terwujud. Terlebih bila hal itu dihadapkan kepada bencana alam yang

\footnotetext{
${ }^{10}$ Wahyu Dwi Prasetyo, United Natons Framework Convertion on Climate change (UNFCCC) 3-14 December 2007, diposting pada 18 sempetmber 2008. Dalam https:// wahyumedia. wordpress.com/ 2008/09/18/united-nations-framework-convention-on-climate-change-unfccc-i-3. 14-december- 2007/. Diakses 15 September 2017. 22

${ }^{11}$ Soemarwoto, Ekologi, Lingkungan Hidup dan Pembangunan (jakarta: Djambatan, 1994), cet. IV.,

${ }^{12}$ Odum, Basic Ecology (New York: Sounders College Publishing, 1983), 29. Karena itu ekologi pada masa awal perkembangannya sering disebut sebagai cabang dari biologi yang membahas tentang ekosistem. Lihat Suroyo, dkk., Ensiklopedi Sains dan Kehidupan (Jakarta: Tarity Samudra Berlian, 2003), cet. II., 49-51.
} 
semakin tahun terkesan semakin meningkat. Maka, upaya optimal keberperanan pemerintah dengan berbagai pihak semakin dituntut keseriusannya ditengah fenomena alam yang semakin sulit diprediksi.

Sebagai contoh, memelihara dan memanfaatkan sumber daya alam yang ada di hutan. Departemen Kehutanan mencoba dan berusaha merangkul semua pihak untuk berperan secara bersama-sama dalam pembangunan kehutanan. Untuk itu, pada Kongres Kehutanan Dunia 1978 yang diselenggarakan di ibu kota Jakarta, semangat forest for people atau hutan untuk rakyat terus berkembang sesuai dinamika yang ada,. Pemerintah dan Perum Perhutani kemudian mengembangkan Perhutanan Sosial hingga kemudian bertransformasi menjadi PHBM, Pengelolaan Hutan Bersama Masyarakat. Kelompok masyarakat sipil kemudian mempromosikan SHK atau Sistem Hutan Kerakyatan. Kemudian dikembangkan project Hutan Kemasyarakatan hingga kemudian mendorong lahirnya kebijakan tentang $\mathrm{HKm}$, juga Hutan Desa, dan Kemitraan, yang merupakan skema pemberdayaan masyarakat setempat di dalam dan sekitar hutan. $^{13}$

Peran serta masyarakat kegiatan penanaman untuk penghijauan dan perbaikan lingkungan hidup searah dengan tujuan Gerakan Rehabilitasi Hutan dan Lahan (GERHAN) sejak 2003. Gerakan ini diharapkan mendapat dukungan dari seluruh lapisan masyarakat, mulai dari kelompok masyarakat yang termuda, hingga orang dewasa serta kaum tua. Agar menarik minat serta menumbuhkan budaya menanam sejak usia dini, Departemen Kehutanan telah mencanangkan kegiatan, Kecil Menanam Dewasa Memanen (KMDM) dalam rangka mendukung Gerakan Nasional Rehabilitasi Hutan dan Lahan (GERHAN) itu. Kegiatan ini akan melibatkan anak-anak usia sekolah dari SD dan Madrasah Ibtidaiyah di seluruh Indonesia dan telah mendapat dukungan dari lembaga-lembaga pendidikan tingkat dasar hingga perguruan tinggi. ${ }^{14}$

\footnotetext{
${ }^{13}$ Istilah ekosistem ini diperkenalkan oleh A.G. Tansley tahun 1935. Lihat A. G. Tansley, "The Use and Abuse of Vegetational Concepts and Terms", Ecology, Vol. 16, No.

${ }^{14}$ Al-Qurean menyebutkan hubungan manusia dan alam sebagai pemelihara, hal itu disebutkan dalam beberapa surat, antara lain, al-Anbiya" ayat 107 yang artinya "dan tiadalah kami mengutus kamu, melainkan untuk (menjadi) rahmat bagi seluruh alam. Surat ali Imran ayat 191 dan as-Sajadah ayat 7 yang mengandung
} 


\section{Alamisasi Islam}

Agama Islam menuntun manusia mempunyai peranan penting dalam menjaga kelestarian alam (lingkungan hidup). Islam memandang lingkungan sebagai bagian yang tidak terpisahkan dari keimanan seseorang terhadap Tuhannya, manifestasi dari keimanan seseorang dapat dilihat dari perilaku manusia, sebagai khalifah terhadap lingkungannya. Islam mempunyai konsep yang sangat detail terkait pemeliharaan dan kelestarian alam (lingkungan hidup). ${ }^{15}$

Surat Luqman ayat 20 Allah berfirman, "Tidakkah kau cermati bahwa Allah telah menjadikan sumber daya alam dan lingkungan sebagai daya dukung lingkungan bagi kehidupanmu secara optimum. Entah demikian, masih saja ada sebagian manusia yang mempertanyakan kekuasaan Allah secara sembrono. Yakni mempertanyakan tanpa alasan ilmiah, landasan etik dan referensi memadai." Dan juga dalam Surat Al Jaatsiyah 13; "Dan Allah telah menjadikan sumber daya alam dan lingkungan sebagai daya dukung lingkungan bagi kehidupan manusia. Yang demikian hanya ditangkap oleh orang-orang yang memiliki daya nalar memadai.'

Firman tersebut merupakan pondasi betapa pentingnya peran agama ikut andil dalam pengelolaan lingkungan hidup oleh para pemeluknya. Namun, pada prakteknya, kesadaran pemeluk masih belum optimal, karena kurangnya solidarisme dan kekompakan dalam menjaga kelestarian lingkungan. Karena faktor dari manusia itu sendiri yang memiliki naluri perusak sebagaimana disebutkan dalam al-Baqarah 31-32 bahwa manusia memiliki kecenderungan sebagai perusak di muka bumi ini. Karena itu, Gzahali menyebutkan beberapa hal sikap muslim dalam merealisasikan fitrahnya dalam menjaga lingkungan, yaitu: 1) bersikap apresiatif; dimaksudkan menghargai keberadaan lingkungan hidup. 2) bersikap kreatif; dalam arti menumbuhkan daya cipta melihat objek dalam hal ini lingkungan agar bisa dimanfaatkan untuk kebaikan. 3) bersikap proaktif; didasarkan pada al-Qashas yang intinya muslim jangan sampai berbuat kerusakan

makna bahwa segala ciptaan dialam jagat raya ini memiliki tujuan. Atau bisa disebut ada asas manfaat, bahkan hewan terkecil pun memiliki kemanfaatannya tersendiri.

${ }^{15}$ Eva Fauziyah dan Dian Diniyati, Identifikasi fakor utama pondok pesantren dalam pegembangan hutan rakyat, jurnal analisis kebijakan kehutanan, vol. 8 no. 1, April 2011, 77-97. Diakses melalui puspijak.org/ uploads/ kebijakan.8.1.2011.5. Fauziah. pdf, pada 4 Januari 2015. 
dimuka bumi, 4) bersikap produktif; dimaksudkan mengolah alam lingkungan sesuai dengan kebutuhan bersama atau kemaslahatan. ${ }^{16}$

Secara umum, istilah alamisasi adalah membawa sesuatu ke dalam alam atau membuatnya dan menjadikannya Islam. Definisi ini bukan berarti Islam tidak bersifat universal, tapi lebih berarti bahwa di luar Islam ada berbagai macam hal yang jauh dari nilai-nilai Islam. Dari sini justru istilah alamisasi merupakan gambaran universal sebagai langkah atau suatu usaha untuk memahamkan sesuatu dengan kerangka Islam (Islamic framework) dengan memasukkan suatu pemahaman Islam. Untuk itu, pemahaman atau sesuatu yang jauh dari nilai Islam tersebut ketika masuk dalam wilayah Islam dibutuhkan adanya upaya yang disebut sebagai alamisasi.

Gagasan alamisasi sama dengan membumikan ilmu pengetahuan, proses tersebut pada hakikatnya muncul sebagai respon atas dikotomi antara ilmu agama dan sains yang dimasukkan Barat sekuler dan budaya masyarakat modern ke dunia Islam. Kemajuan yang dicapai sains modern telah membawa pengaruh yang menakjubkan, namun di sisi lain juga membawa dampak yang negatif, karena sains modern (Barat) kering nilai atau terpisah dari nilai agama. Selain istilah alamisasi yang agak asing, dikenal pula istilah Islamisasi ilmu pengetahuan juga merupakan reaksi atas krisis sistem pendidikan yang dihadapi umat Islam, yakni adanya dualisme sistem pendidikan Islam dan pendidikan modern (sekuler) yang membingungkan umat Islam.

Secara historis, ide atau gagasan alamisasi ilmu pengetahuan muncul pada saat diselenggarakan konferensi dunia yang pertama tentang pendidikan Islam di Makkah apad tahun 1977. Konferensi yang diprakarsai oleh King Abdul Aziz University berhasil membahas 150 makalah yang ditulis oleh sarjana-sarjana dari 40 negara, dan merumuskan rekomendasi untuk pembenahan serta serta penyempurnaan sistem pendidikan Islam yang diselenggarakan oleh umat Islam seluruh dunia. Salah satu gagasan yang direkomendasikan adalah menyangkut Islamisasi ilmu pengetahuan. Gagasan ini di antaranya dilontarkan oleh Syed M.

\footnotetext{
${ }^{16}$ Abdillah, Mujiyono. Agama ramah lingkungan: perspektif Al-Qur'an. Vol. 6. Penerbit Paramadina, 2001. H. 80-85.
} 
Naquib al-Attas dengan makalah yang berjudul "Preliminary Thoughts on the Nature of Knowledge and the Definition and Aims of Education" dan Ismail Raji al- Faruqi dalam makalahnya "Islamicizing social science. ${ }^{17}$

Inti utama dari visi Islamisasi pengetahuan al-Faruqi adalah, menganggap kelumpuhan politik, ekonomi, dan religio-kultural umat Islam terutama merupakan akibat dualisme sistem pendidikan di dunia Muslim. Di samping juga karena hilangnya identitas dan tak adanya visi, dia yakin bahwa obatnya ada dua; mengkaji peradaban Islam dan Islamisasi pengetahuan modern.

Tauhid juga dipahami sebagai pandangan umum tentang realitas, kebenaran, dunia, ruang dan waktu, sejarah manusia. Dengan demikian, tauhid memberikan identitas peradaban Islam yang mengikat semua unsur-unsurnya bersama-bersama dan menjadikan unsur-unsur tesebut suatu kesatuan yang integral dan organis yang disebut peradaban. Ada pun tauhid mengandung 5 prinsip dasar, yaitu:

a. Dualitas

Realitas terdiri dari dua jenis yang umum Tuhan dan bukan Tuhan; Khalik dan makhluk. Jenis yang pertama hanya mempunyai satu anggota yakni Allah Swt. Hanya Dialah Tuhan yang kekal, Maha Pencipta yang transenden. Tidak ada sesuatupun yang serupa dengan Dia. Jenis kedua adalah tatanan ruang waktu, pengalaman, dan penciptaan. Di sini tercakup semua makhluk, dunia bendabenda, tanaman dan hewan, manusia, jin, dan malaikat dan sebagainya. Kedua jenis realitas tersebut yaitu khaliq dan makhluk sama sekali dan mutlak berbeda sepanjang dalam wujud dan ontologinya, maupun dalam eksistensi dan karir mereka. selamanya sangat mustahil kalau keduanya menjadi satu atau pun lebur. ${ }^{18}$ b. Ideasionalitas

Hubungan antara dua tatanan realitas ini bersifat ideasional yang titik acuannya dalam diri manusia adalah pada kekuatan pemahaman. Pemahaman digunakan untuk memahami kehendak tuhan melalui pengamatan dan atas dasar

\footnotetext{
${ }^{17}$ Muhaimin, 7 |Tadrib Vol. II No. 2 Edisi Desember 2016 2003: 330)

${ }^{18}$ Zuhdiyah. Islamisasi Ilmu Ismail Raji al-Faruqi |Tadrib Vol. II No. 2 Edisi Desember 2016. Dosen Fakultas Ilmu Tarbiyahdan Keguruan UIN Raden Fatah Palembang, h. 41
} 
penciptaan kehendak sang penguasa yang harus diaktualisasikan dalam ruang dan waktu, berpartisipasi dalam aktivitas dunia serta menciptakan perubahan yang dikehendaki. Sebagai prinsip pengetahuan, tauhid adalah pengakuan bahwa Allah itu ada dan Esa. Pengakuan bahwa kebenaran itu bisa diketahui dan manusia mampu mencapainya. ${ }^{19}$

c. Teleologi

Dunia tidak diciptakan secara kebetulan, dunia diciptakan dalam kondisi sempurna. Dunia merupakan kosmos ciptaan yang teratur bukan kekacauan. Di dalamnya kehendak pencipta selalu terjadi. Allah adalah tujuan terakhir alam semesta, berarti bahwa manusia mempunyai kesanggupan untuk berbuat, bahwa alam semesta dapat ditundukkan atau dapat menerima manusia. Pada manusia terdapat fungsi fisik dan spiritual. Fungsi fisik dan manusia bersatu dengan alam, sehingga mereka mematuhi hukum-hukum yang mengikat mereka dengan keharusan yang sama seperti makhluk lainnya. Fungsi spiritual, yaitu pemahaman dan perbuatan moral berada di luar bidang alam yang sudah ditentukan. Mereka bergantung pada subjeknya dan menuruti ketetapannya. ${ }^{20}$

\section{Kemampuan Manusia dalam Mengelola Alam}

Oleh karena segalanya diciptakan untuk suatu tujuan, maka realisasi tujuan itu harus terjadi dalam ruang dan waktu. Manusia harus mampu mengubah dirinya, masyarakatnya, dan alam lingkungannya, mengaktualisasikan perintah ilahiyah dalam dirinya mau pun dalam mereka. bahwa manusia mempunyai kesanggupan untuk berbuat dan mempunyai kemerdekaan untuk tidak berbuat. Kemerdekaan ini memberi manusia sebuah tanggungjawab terhadap segala tindakannya.

\section{Tanggung Jawab dan Penilaian}

Oleh karena manusia berkewajiban mengubah dirinya, masyarakatnya dan lingkungannya, agar selaras dengan pola Tuhan, dan mampu berbuat demikian, (1976). h. 29

${ }^{19}$ al Fārūqī, Ismáîl Rāgī, and David E. Sopher. "Historical Atlas of the Religions of the World."

${ }^{20}$ Al-Faruqi, Ismail Raji. Al Tawhid: Its Implications On Thought And Life. Vol. 4. IIIT, 1992. h. 26 
dan jika seluruh objek tindakannya dapat dibentuk dan dapat menerima tindakannya serta mewujudkan maksudnya, maka dia bertanggung jawab. Kewajiban moral mustahil tanpa adanya tanggung jawab. Sedangkan penilaian atau pelaksaan tanggung jawab merupakan syarat mutlak kewajiban moral. Perhitungan dapat saja terjadi dalam ruang dan waktu atau pada akhir zaman yang pasti terjadi. Mentaati Tuhan adalah mewujudkan perintah-Nya dan pola-Nya untuk mencapai Allah sedangkan tidak mentaatinya, berarti mendatangkan hukuman, penderitaan, kesengsaraan, dan kegagalan.

Untuk merubah paradigma sekulerisme di dunia Islam, al-Faruqi meletakkan prinsip tauhid sebagai kerangka pemikiran, metodologi dan cara hidup Islam. Prinsip prinsip tauhid itu terdiri dari lima macam kesatuan, yaitu: ${ }^{21}$

a. Keesaan (kesatuan) Tuhan, implikasinya dalam kaitannya dengan ilmu pengetahuan, bahwa sebuah pengetahuan bukan untuk menerangkan dan memahami realitas, melebihkan melihatnya sebagai bagian yang integral dari eksistensi tuhan. Karena itu, islamisasi ilmu mengarahkan pengetahuan pada kondisi analisa dan sintesa tentang hubungan realitas yang dikaji dengan hukum Tuhan.

b. Kesatuan ciptaan, bahwa semesta ini baik yang material psikis spasial (ruang), biologis maupun etnis adalah kesatuan yang integral. Dalam kaitannya dengan Islamisasi ilmu, maka setiap penelitian dan usaha pengembangan keilmuan harus diarahkan sebagai refleksi dari keimanan dan realisasi ibadah kepadanya

c. Kesatuan kebenaran dan pengetahuan, kebenaran bersumber pada realitas, dan realitas bersumber dari satu yaitu Tuhan. Maka, apa yang disampaikan lewat wahyu tidak bertentangan dengan realitas yang ada, karena keduanya diciptakan oleh Tuhan.

d. Kesatuan hidup yang meliputi amanah, khilafah, dan Kaffah (Komprehensif).

e. Kesatuan manusia yang universal mencakup seluruh umat manusia tanpa terkecuali. Maka, pengembangan sains harus berdasar pada kemaslahatan

\footnotetext{
${ }^{21}$ Azra, Azyumardi. "Networks of the Ulama in the Haramayn: Connections in the Indian Ocean Region." Studia Islamika 8.2 (2001).
} 
manusia secara universal. Lebih lanjut, sebagai prinsip metodologi, tauhid terdiri dari tiga prinsip kebenaran, yaitu:

a) Menolak semua yang tidak berkaitan dengan realitas, yakni melindungi seorang muslim dari membuat pernyataan yang tidak teruji, tidak jelas terhadap ilmu pengetahuan. Pernyataan yang kabur merupakan contoh yang di larang dalam al-Qur'an.

b) Menafikan semua hal-hal yang sangat bertentangan, artinya melindungi dari kontradiksi di satu pihak, dan paradoks di pihak lain. Rasionalisme bukanlah mengutamakan akal atas wahyu tetapi penolakan terhadap kontradiksi puncak antara keduanya.

c) Terbuka terhadap bukti baru dan atau/berlawanan. Hal ini melindungi seorang muslim dari literalisme, fanatisme, dan konservatisme yang menyebabkan stagnasi. Prinsip ketiga ini mendorong kaum muslimin untuk bersikap rendah hati intelektual.

Bahkan dalam kehidupan beragama, setiap muslim dilatih dan diwajibkan melakukan pembersihan terhadap diri sendiri dalam setiap shalat yaitu melalui bersuci. Artinya, kepedulian diri terhadap kebersihan menjadi prioritas. Dengan pembiasaan yang terus menerus tersebut, muslim diharapkan mampu menerapkannya dalam tataran makro diluar dirinya, yaitu dilingkungan sekitar. Termasuk dokrin Islam dalam melakukan penyucian terhadap kotoran dan najisa yang ada, baik dari pengaruh hewan yang telah ditentukan dalam nash (seperti anjing) ataupun lainnya yang menuntut pelaksanaan konsep penyucian (thaharah).

Dengan demikian, dasar atau pedoman dalam agama Islam, menyelaraskan keseimbangan antara pengolahan sumber daya alam yang ada disekitar demi kepentingan bersama yang lebih baik. Tidak berbuat yang merugikan kendatipun salah satu fitrah manusia adalah perusak. Ada upaya meminimalisir potensi negatif dengan saling mengingatkan bahwa yang merugikan lingkungan itu pada hakikatnya adalah merugikan manusia itu sendiri. 


\section{Belajar dari lingkungan}

Di Indonesia telah banyak berdiri organasisasi non pemerintah (NGO) ataupun komunitas yang peduli terhadap pelestarian lingkungan baik yang didasarkan atas motivasi agama maupun lainnya. Hal itu didasarkan atas Perkembangan permasalah perubahan iklim yang semakin membawa kekhawatiran bagi para penduduk dunia hari demi hari. Beberapa diantaranya, yaitu WWF, Walhi setingkat nasional dan lainnya yang ada ditingkat regional.

Pertama; WWF Indonesia adalah salah satu organisasi konservasi independen terbesar di Indonesia yang telah memulai kegiatannya sejak 1962. Pada tahun 1998, WWF Indonesia resmi menjadi lembaga nasional berbadan hukum yayasan. Kini, WWF Indonesia berada di 28 kantor wilayah di 17 propinsi, menjalin kerjasama dan bermitra dengan masyarakat, LSM, media, dunia usaha, universitas, serta pemerintah baik di daerah maupun pusat. Didukung oleh lebih dari 500 personil. Sejak tahun 2006, WWF Indonesia mendapatkan dukungan lebih dari 64,000 supporter yang tersebar di seluruh penjuru Nusantara.25 Pada tahun 1996, WWF resmi berstatus yayasan, menjadi sebuah entitas legal, yang berbadan hukum sesuai ketentuan di Indonesia. Prof. Emil Salim, Pia Alisjahbana dan Harun Al Rasjid (alm) merupakan salah satu yang menjadi pendorong berdirinya Yayasan WWF Indonesia, menempatkannya sebagai organisasi nasional dalam Jaringan Global WWF, yang memiliki Dewan Penyantun sendiri, independen dan fleksibel dalam penggalangan dana dan pengembangan program. Tahun 2015 ini WWF telah berumur 53 tahun kegiatan konservasi WWF di Indonesia. ${ }^{22}$

Kedua; organisasi Wahana Lingkungan Hidup Indonesia (WALHI) memiliki visi terwujudnya suatu tatanan sosial, ekonomi dan politik yang adil dan demokratis yang dapat menjamin hak-hak rakyat atas sumber-sumber kehidupan dan lingkungan hidup yang sehat dan berkelanjutan. Organisasi ini adalah sebuah organisasi gerakan lingkungan hidup terbesar di Indonesia, dengan jumlah anggota sebanyak 483 organisasi dan tersebar di 27 propinsi. Bermula tahun 1980

\footnotetext{
${ }^{22}$ Indrawan, Mochamad, Richard B. Primack, and Jatna Supriatna. Biologi Konservasi: Biologi Konservasi. Yayasan Pustaka Obor Indonesia, 2012. h. 19
} 
hingga kini WALHI secara aktif mendorong upaya-upaya pemulihan dan penyelamatan lingkungan hidup, terutamanya pada kelestarian hutan dan keanekaragaman hayati yang terancam terdegradasi oleh model pembangunan di sektor kehutanan yang eksploitatif dan tidak berkelanjutan. WALHI sadar kecenderungan kerusakan lingkungan hidup semakin masif dan kompleks baik di pedesaan dan perkotaan. Memburuknya kondisi lingkungan hidup secara terbuka diakui mempengaruhi dinamika sosial-politik dan sosial-ekonomi masyarakat baik di tingkat komunitas, regional, maupun internasional. ${ }^{23}$

Pada gilirannya krisis lingkungan hidup secara langsung mengancam kenyamanan dan meningkatkan kerentanan kehidupan setiap warga negara. Siapa yang bertanggung jawab atas kerusakan lingkungan hidup kian sulit dipastikan karena penyebabnya sendiri saling bertautan baik antar sektor, antar aktor, antar institusi, antar wilayah dan bahkan antar negara. Untuk menjamin keberlanjutan kehidupan generasi mendatang dibutuhkan gerakan sosial yang kuat dan meluas. Generasi mendatang berhak atas lingkungan hidup yang baik dan sehat. Untuk itu generasi sekarang bertanggungjawab mempertahankan dan meningkatkan kualitas lingkungan yang lebih baik.

Ketiga; ditingkat regional ibu kota, banyak berkembang komunitas pecinta lingkungan dari berbagai latar belakang. Pada tahun 2011, didirikan Komunitas Peduli Lingkungan Hidup Indonesia (KPLHI) terdiri dari anggota facebookers, organisasi non pemerintah, Kelompok Pencinta Alam, Kelompok Swadaya Masyarakat, Sekolah, dan Perorangan, atas dasar kebersamaan membangun lingkungan hidup. Lingkungan Hidup merupakan elemen terpenting dalam kelanjutan hidup anak dan cucu dimasa depan. ${ }^{24}$

Keempat; organisai Tunas Hijau (TH). Ini merupakan organisasi pecinta lingkungan yang ada ditingkat regional. Organisasi ini merupakan organisasi lingkungan hidup non-profit, kids \& young people do actions for a better earth yang bermarkas di Surabaya. TH berawal dari pengiriman 5 orang pemuda dari Jawa Timur ke Australia, Maret 1999. Mulai saat itu, TH terus konsisten dalam

\footnotetext{
${ }^{23}$ Zakaria, R. Yando. Hutan dan kesejahteraan masyarakat lokal. Wahana Lingkungan Hidup, 1994.

${ }^{24}$ Keraf, A. Sonny. Etika lingkungan hidup. Penerbit Buku Kompas, 2010. h. 113
} 
melakukan upaya sederhana, nyata dan berkelanjutan untuk membantu lingkungan hidup menjadi lebih baik. TH menerima Surabaya Academy Award 2004 dalam bidang lingkungan hidup. Pada Surabaya Academy Award 2004 ini Tunas Hijau menjadi organisasi lingkungan hidup pertama yang mendapatkannya. Tunas Hijau juga mendapatkan Delta FM Surabaya Award 2005 untuk kategori lingkungan hidup dari jaringan Radio Delta FM Jawa Timur. ${ }^{25}$

Program lingkungan hidup yang diprakarsai Tunas Hijau lebih diprioritaskan pada program yang berkelanjutan untuk menciptakan lingkungan hidup yang lebih baik. Metode yang digunakan dalam kampanye lingkungan hidup pun semakin lama semakin berkembang seiring trend masyarakat. Tunas Hijau telah mengembangkan beberapa media permainan yang sudah banyak dikenal masyarakat Indonesia menjadi media pendidikan lingkungan hidup.

Diantara media permainan tersebut adalah kartu kwartet, monopoli, kartu remi dan ular tangga. Khusus untuk ular tangga, Tunas Hijau bahkan telah menerbitkan beberapa tema ular tangga, yaitu lapisan ozon, hutan, papua, sampah, pemanasan global, air dan lingkungan hidup. Tunas Hijau telah menerbitkan beberapa buku komik tema lingkungan hidup. Buku komik yang telah diterbitkan adalah: Ayo Tanam Pohon, 2005 dan 2008; Monster Sampah Plastik, 2006; Air, 2007; Duta Ozon, 2007; Papuaku Mutiaraku, 2006; Lindungi Lapisan Ozon, 2007; Climate Change Threat, 2007; Perubahan Iklim Mengancam, 2007, Perth Royal Show 2008; dan Kota Berselimut Asap, 2008.

Organisasi yang telah disebutkan diatas, hanyalah bagian kecil dari kepedulian warga masyarakat terhadap pelestarian lingkungan. Sayangnya, menurut pemakalah, kurangnya program integratif antara organisasi dengan generasi muda yang masih kurang peduli terhadap lingkungan. Bahwa moyoritas pemuda pemudi di Indonesia, masih mengalami kekurangpahaman pentingnya peran wadah pecinta lingkungan dalam kehidupan sehari-hari. Khusunya bila dihadapkan pada generasi terpelajar yang sedang mengenyam pendidikan formal dari tingkat dasar sampai perguruan tinggi.

\footnotetext{
${ }^{25}$ Desfandi, Mirza. "Mewujudkan masyarakat berkarakter peduli lingkungan melalui program adiwiyata." SOSIO-DIDAKTIKA: Social Science Education Journal 2.1 (2015): 31-37.
} 


\section{Menunggu Punahnya Generasi}

Begitu besar peranan dan tanggungjawab manusia dalam menjaga kelestarian alam, menuntut kebijakan dari setiap diri manusia untuk ikut andil secara optimal dalam menjaga ekosistem bumi. Setidaknya, dengan mengaktifkan diri dalam semua organisasi atau wadah yang telah ada di negara ini agar peran bisa lebih otpimal. Pemakalah, menganalisa bahwa generasi muslim masih perlu memotivasi diri dalam hal pemahaman terhadap pentingnya ilmu ekologi. Karena ilmu ini sangat erat sekali dengan kehidupan sehari-hari. Semua aspek dalam kehidupan kita tak lepas dari keutuhan alam sekitar. Karena masih banyak umat muslim kurang memperhatikan kelestarian lingkungan karena faktor minimnya pemahaman terhadap strategi dalam melestarikan lingkungan.

Generasi muslim yang sedang fokus dalam mempelajari keilmuan agama di pesantren khususnya yang salaf, dipastikan sangan minim informasi tentang berbagai hal yang berkaitan dengan fenomena alam disekitarnya. Kejadian atau peristiwa berupa kebakaran hutan, tanah longsor, banjir bandang atau lainnya akan sangat mencengangkan mereka. Bahkan cenderung akan beranggapan bahwa segala yang terjadi itu murni takdir atau kehendak Tuhan. Padahal secara ilmiah segala fenomena tersebut juga bisa dipelajari dan diperinci sebab musababnya berdasarkan ilmu pengetahuan dan dibantu teknologi canggih hasil karya manusia.

Oleh karena itu, penyadaran dan keterbukaan diri dari lembaga pesantren dalam mendidik generasinya menghadapi fenomena alam yang semakin sulit diprediksikan membutuhkan pemahaman jangka panjang dan sosialisasi terhadap mayarakat pesantren yang tidak mudah. Butuh keseriusan dari para pengelola dan pengurus pesantren melakukan kerjasama dengan organasasi pecinta lingkungan yang sudah mapan dan profesional. Jadi, tidak perlu menunggu waktu terjadinya bencana alam, melainkan harus jemput bola dengan membekali pengetahuan lingkungan yang diitegrasikan dengan dokrin agama. Agar tercipta generaasi muda yang islami, relevan disepanjang masa demi kemashlahan lingkungan dan manusia.

Hal itu, bisa dimunculkan program-program atau pelatihan tentang simulasi bencana alam misalnya, atau memberikan keterampilan tentang 
pemanfaatan sampah yang telah lama menumpuk dan menjadi masalah dilingkungan pesantren-pesantren besar. Dimana persoalan sampah itu sendiri merupakan problematika disetiap wilayah baik perkotaan ataupun pedesaan sekalipun. Karena faktanya, banyak sungai dan selokan yang tercemar sampahsampah dari masyarakat itu sendiri. Belum lagi persoalan polusi udara dari transportasi yang semakin meningkatnya penggunaan bahan bakar minyak. Yang menyebabkan kondisi udara disekitar tercemar sehingga mendatangkan penyakit bagi manusia.

\section{Peran Perguruan Tinggi}

Pendidikan di perguruan tinggi, baik berbentuk akademi, politeknik, sekolah tinggi, institut ataupun universitas, harus menyelenggarakan menyelenggarakan pendidikan, penelitian, dan pengabdian kepada masyarakat.30 Biasa dikenal dengan tri dharma perguruan tinggi. ${ }^{26}$ Kesemua perguruan tinggi baik negeri ataupun swasta selain menyelenggarakan harus melakukan evaluasi terhadap kinerja dari tridharma perguruan tinggi masing-masing secara simultan. Penyelenggaraannya dilakukan melalui kerjasama yang baik antara pendidik dosen dan peserta didik mahasiswa. Tidak hanya antara dosen dalam satu perguruan tinggi saja, melainkan lintas sektoral pula harus dilakukan. ${ }^{27}$

Salah satu wujud pengabdian masyarakat bagi mahasiswa adalah kuliah kerja nyata $(\mathrm{KKN})$. Dalam kurun waktu setahun sekali, kesempatan mahasiswa secara resmi menunjukkan pengabdiannya kepada masyarakat melalui kegiatankegiatan sosial bersama dan ditengah masyarakat. Bentuk-bentuk kegiatan bisa berupa kerja bakti tempat ibadah, melakukan perbaikan sarana prasarana desa, ikut andil dalam pengajaran di sekolah dasar sampai menengah, atau melakukan pembinaan dan pelatihan keterampilan dan seterusnya. Khususnya dalam sosialisasi terhadap pentingnya menjaga kelestarian lingkungan di sekitar.

\footnotetext{
${ }^{26}$ Undang-Undang Republik Indonesia Nomor 20 tahun 2003 tentang system pendidikan nasional Pasal 20, ayat 1 dan 2.

${ }^{27}$ Pendidik adalah tenaga kependidikan yang berkualifikasi sebagai guru, dosen, konselor, pamong belajar, widyaiswara, tutor, instruktur, fasilitator, dan sebutan lainyang sesuai dengan kekhususannya, serta berpartisipasi dalam menyelenggarakan pendidikan. Undang-Undang Republik Indonesia Nomor 20 tahun 2003 tentang system pendidikan nasional Pasal 1, ayat 2.
} 
Terutama bagi mahasiswa di bawah perguruan tinggi agama islam negeri dan swasta. Penyelenggaraan pengabdian kepada masyarakat yang cenderung lebih dominan mengarah kepada kegiatan-kegiatan keagamaan. Sehingga, makna dari kegiatan KKN benar-benar dirasakan oleh masyarakat. Seperti yang telah dilakukan oleh mahasiswa UIN Jakarta. Ada tiga jenis program kegiatan KKN, yakni program khusus, program umum dan program tambahan. Program khusus mencakup kegiatan yang dilaksanakan setiap mahasiswa sesuai dengan kompetensinya. Program umum adalah kegiatan yang secara umum dilaksanakan dan tidak terkompetensi, seperti gotong royong, acara-acara diskusi dengan masyarakat dan pembersihan lingkungan. ${ }^{28}$

Oleh karena itu, sosialisasi secara optimal perlu digalakkan lebih matang dikalangan mahasiswa terhadap pentingnya peran perguruan tinggi terhadap masyarakat. Artinya, mahasiswa dibekali keterampilan-keterampilan softskill dalam menyampaikan berbagai dampak negatif dari pencemaran lingkungan dalam berbagai aspeknya, khususnya berkaitan dengan isu kontemporer dampak dari pencemaran lingkungan.

\section{Kesimpulan}

Konsep ilmu ekologi dalam Islam merupakan sebuah keniscayaan untuk dilestarikan dan dikembangkan. Secara praktis kehadirannya seiring dengan dokrin islam yang telah dibawa dan diteladankan oleh pembawanya yaitu Muhammad Saw. Pelan namun pasti, segala aspek kehidupan manusia, tak lepas dari proses perbaikan dan penyempurnaan. Baik berkenaan dengan hal-hal sederhana seperti urusan penyucian diri dari kotoran (najis), sampai hal-hal menyangkut penyucian lingkungan, bahkan jenazah (mayit). Dipastikan tidak ada aspek kehidupan yang terlewatkan dalam konsep Islam berkenaan dengan kebersihan. Karena islam menghendaki kebersihan diri dan lingkungan sekitar.

\footnotetext{
${ }^{28}$ Irma Wahyuni, Mahasiswa KKN perlu adakan kegiatan Monumental, UINJKT Online, di tulis 09 Juli 2009. Dalam www.uinjkt.ac.id. Bahkan ketua LPM UIN Jakarta Dr. Daud Effendy waktu itu menyarankan agar program-program kegiatan yang mengandung nilai-nilai monumental, misalnya instalasi bio gas, instalasi pembuangan limbah pabrik, pendirian koperasi, BMT dan lain-lain," ujar Daud kepada UINJKT Online di sela acara pembekalan KKN di Gedung Aula Madya, Kamis (9/7).
} 
Kendati demikian, pemeluk agama Islam tidak sepenuhnya mau dan mampu mewujudkan konsep tentang pelestarian lingkungan sekitar. Bahkan ada yang cenderung antipati terhadap aturan formal mengenai kebersihan lingkungan sekitar. hal itu terlihat dari kurangnya kesadaran dalam membuang sampah pada tempatnya. Atau kurangnya kesadaran melakukan kebersihan secara massal dan konsisten dalam menjaga lingkungan sekitar. Baik di darat, di laut maupun di udara.

\section{Daftar Pustaka}

Al- Faruqi, Ismail Raji. Tawhid: Its Implication for Thought and Life. New York: April 2011, 77-97. Diakses melalui puspijak.org/uploads/.../kebijakan.8.1.2011.5.\%20Eva\%20Fauziah.PDF, pada 4 Januari 2015

Azizy, A. Qodri. Pendidikan Agama Untuk Membangun Etika Sosial. Semarang: bromo-mulai-lontarkan-lava-pijar Cv. Aneka Ilmu, 2003. cet. 2.

Dalam https://wahyumedia.wordpress.com/2008/09/18/united-nations-frameworkconvention-on-climate-change-unfccc-i-3-\%E2\%80\%93-14-december2007/. Diakses 15 Juni 2015. dan nasruddin harahap, masalah kependudukan dan lingkungan hidup. Di mana visi Islam?. Yogyakarta: P3M IAIN Sunan Kalijaga, 1990 Diakses 4 Januari 2015 diposting senin, 9 Februari 2015. source:http://metro.sindonews.com/ read/ 961753/31/ tercemar-limbah-air-kali-bekasi-masih-layak-konsumsi-1423397037. Diakses pada 26 Mei 2015. Djambatan, 1994), cet. IV.

El-Dusuqy, Fajar. Ekologi al-Qur"an; Menggagas Ekoteologi-Integralistik, $e$ Jurnal Kaunia, Vol. IV, No. 2, Oktober 2008, 173-189, http://digilib.uinsuka.ac.id/id/eprint/710 .

Fauziyah, Eva dan Dian Diniyati, Identifikasi fakor utama pondok pesantren dalam pngembangan hutan rakyat, jurnal analisis kebijakan kehutanan, vol. 8 no. 1 ,

Ghazali, M. Bahri . Lingkungan Hidup dalam pemahaman Islam. Jakarta: Pedoman Ilmu Jaya, 1996.

Hadiwojono, Harun. sari sejarah filsafat barat 2. Yogyakarta: Kanisius, 1992 Harjasoemantri, Koesnadi. "pokok-pokok masalah lingkungan, dalam siti zawimah 
Odum, Basic Ecology. New York: Sounders College Publishing, 1983. pendidikan nasional Pasal 20, ayat 1 dan 2.

Peraturan Menteri Kehutanan No. P.33/menhutV/2005 tanggal 01 Nopember 2005 tentang Pedoman dan Petunjuk Pelaksanaan Kegiatan Gerakan nasional Rehabilitasi Hutan dan Lahan. Lihat Purwoko Soebianto, Gerakan Rehabilitasi Hutan dan Lahan; Mau Melankah Kemana?, dalam dishut.jabarprov.go.id/.../Gerakan\%20Rehabilitasi\%20Hutan\%20dan\%20.

Peraturan Presiden Republik Indonesia nomor 89 tahun 2007. Diunduh melalui www.datakesra.kemenkopmk.go.id/content/program-gerakan-nasionalrehabilitasi-hutan-dan-lahan-gerhan. diakses 4 Januari 2015.

Prasetyo, Wahyu Dwi. United Natons Framework Convertion on Climate change (UNFCCC) 3-14 December 2007, diposting pada 18 sempetmber 2008.

Surjaya, Abdullah M. "Tercemar Limbah. Air Kali Bekasi Masih Layak Konsumsi”.

Suroyo, dkk., Ensiklopedi Sains dan Kehidupan. Jakarta: Tarity Samudra Berlian, 2003), cet. II., 49-51.

Tansley, A. G. "The Use and Abuse of Vegetational Concepts and Terms", Ecology, Vol. 16, No. 3. (Jul., 1935), pp. 284-307. http://www.jstor.org Wed Mar 12 16:16:48 2008. Diakses 26 Mei 2015.

Undang -undang RI, Nomor 4 tahun 1982 tentang ketentuan-ketentuan pokok pengelolaan lingkungan hidup Bab III, pasal 9, 7.

Undang-undang RI nomor 23 tahun 1997 tentang pengelolaan lingkungan hidup. Undang-Undang Republik Indonesia Nomor 20 tahun 2003 tentang system.

Utina, Ramli. Pemanasan Global; dampak dan upaya meminimalisasinya, dalam repository.ung.ac.id/.../Pemanasan-Global-Dampak-dan-Upaya-M.

Wahyuni, Irma. Mahasiswa KKN perlu adakan kegiatan Monumental, UINJKT Online, di tulis 09 Juli 2009. Dalam www.uinjkt.ac.id. UINJKT Online .

Yunus dkk., Andri Santoso (ed.) Kehutanan Masyarakat Pengalaman dari Lapangan. Bogor: Forum Komunikasi Kehutanan Masyarakat, 2012.

http://tunashijau.org/profil/

http://www.cnnindonesia.com/internasional/20150426145318-106-49287/gempa- 
http://www.menlh.go.id/peluncuran-hari-lingkungan-hidup-2015-dan-pekanlingkungan indonesia-ke-19/ diakses 30 desember 2015.

http://www.walhi.or.id/visi-misi-walhi diakses pada 30 Desember 2015

http://www.wwf.or.id/tentang_wwf/visi_dan_misi2/ diakses pada 30 Desember 2015.

http://www.wwf.or.id/tentang_wwf/whoweare/diakses30.Desember 2015 https: //www.change.org/ id/ organisasi /f4 Machmillan Publishing, 1982. 